\title{
Corrosion mitigation of buried structures by soils modification
}

\author{
Mitigación de la corrosión de estructuras enterradas mediante \\ la modificación de suelos
}
V. C. Córdoba ${ }^{1}$,
M. A. Mejía ${ }^{1}$,
F. Echeverría ${ }^{1}$,
M. Morales ${ }^{2}$,
J. A. Calderón ${ }^{1}$

Recibido 8 de septiembre de 2011, aceptado 19 de diciembre de 2011

Received: September 8, 2011 Accepted: December 19, 2011

\begin{abstract}
RESUMEN
Muestras de acero al carbono fueron enterradas en el suelo arcilloso modificado con cal, ceniza volante y cemento Portland en proporción de 5 y un $10 \%$ durante 60 días. El ataque corrosivo fue evaluado mediante espectroscopía de impedancia electroquímica. Muestras de suelo arcilloso sin modificación fueron tomadas como referencia. Los productos de corrosión se caracterizaron por espectroscopía Raman. Se encontró que el suelo con la adición de cenizas volantes y el cemento Portland puede desarrollar protección contra la corrosión del acero desnudo por la modificación del óxido formado sobre muestras de acero. La lepidocrocita y goetita se encontraron como los principales componentes de la herrumbre formada en el acero enterrado en suelos modificados con cenizas volantes y cemento, mientras que la magnetita se encuentra en la herrumbre formada en el acero enterrado en suelo modificado con cal y el suelo sin modificación. De acuerdo con los resultados electroquímicos, el suelo modificado con un 5\% de cenizas volantes mostró el mejor desempeño anticorrosivo.
\end{abstract}

Palabras clave: Acero al carbono, corrosión en suelos, modificación de suelos, impedancia electroquímica, espectroscopía Raman.

\section{ABSTRACT}

Carbon steel samples were buried in loamy soil modified with lime, fly-ash and Portland cement in ratio of 5 and 10\% during 60 days. Corrosion attack was assessed by electrochemical impedance spectroscopy. Loamy soil without modification was taken as reference. The corrosion products in rust were characterized by Raman spectroscopy. It was found that soil with fly-ash and Portland cement can develop corrosion protection to bare steel due to the changing of formed rust on steel samples. Lepidocrocite and Goethite were found as major constituents in formed rust on buried steel in soil modified with fly-ash and cement, while Magnetite was found in formed rust on buried steel in soil without addition of cementitious materials and modified with lime. According to the electrochemical results, the soil with 5\% of fly-ash exhibited the anticorrosive best performance.

Keywords: Carbon steel, soil corrosion, soil modification, electrochemical impedance, Raman spectroscopy.

\section{INTRODUCTION}

The study of soil as a corrosive medium is important taking into account the large amount of buried structures. The deterioration of that kind of structures could represent economic, safety, and environmental problems through the years.

According to Trabanelli, Zucchi and Arpaia, soil can be considered as a porous heterogeneous system

1 Grupo de Corrosión y Protección-CIDEMAT, Universidad de Antioquia. PBox 1226. Tel: 574-2196617. Medellín, Colombia. E-mail: jacalder@udea.edu.co

2 Grupo de Ingeniería Civil GICI- Universidad de Medellín. Carrera 87, No. 30-65. Medellín, Colombia. Tel:(574)3405586. 
with colloidal characteristics [1]. The holes between soil particles can be filled with water and/or gas. When soil is compared to another medium, such as the atmosphere or sea water, it is difficult to make a classification of its aggressiveness because of its complexity [2]. The corrosiveness of the soil can be defined as the capacity of producing and developing the corrosion phenomenon. Soil is defined as an electrolyte and can be studied by electrochemical methods.

Studies related to soils have been of great value for implementing new techniques and technologies for the construction of the building foundations, electrical transmission tower foundations, highways, and roads, etc. One of the fields that has focused in the study of soils is the road construction because of the diversity of geographical and climatic conditions which can influence changes in the properties and composition of the soil in a determined distance respect to the starting point, making that the construction methods change as a function of the soil qualities to guarantee the functionality and duration of the infrastructure on the soil [3].

A good choice to avoid heterogeneities in soils which occur during the development of roads is to stabilize them to achieve constant properties. The most commonly used materials for the stabilization and modification of soils are the cementitious agents among which are the cement, lime, fly-ash or a mixture of them [3]. These materials give specific properties to the soil such as increase in bearing capacity, mechanical resistance, and permeability, among others $[4,5]$. Changes in those properties are due to a series of reactions, which can occur between the material and the soil. These reactions are determined by variables like temperature, composition, relative humidity, and $\mathrm{pH}[6,7]$. However, while this procedure has been very effective, its use has been limited due to lack of long-term effectiveness [3,8].

During the last 30 years, specialized companies have increased the quantity of products resulting from the carbon burning. These products become ingredients of concrete, mortar, bricks, paints, and different construction materials. In addition, these products are used in soil stabilization, and they could be as structural filler or as base layer materials on roads
[8]. In the last decade, the use of waste obtained by carbon burning has increased more than $50 \%$.

Most of performed researches in soil modification technique have been focused in the improvement of mechanical properties. Nevertheless, the use of this technique as a control and prevention method for buried structures corrosion has not been well explored. Large structures like water, gas and oil pipelines, electric and telephone cables distributed through metallic tubes, bridge anchors or power lines are normally exposed to soils of diverse aggressiveness, so the integrity of those structures must be tested [9]. When it comes to protect buried structures in soils, materials with high corrosion resistance are commonly used with the purpose of isolating the structures from the medium [10-12].

Amer, Al-Rawas and Al-Sarmi [13] evaluated the modification of high plasticity silt with lime, cement, and a combination of them. They used three rates for additions, 3\%, 6\%, 9\% (w/w) of dry soil, taking as a reference the soil without modification. They found that the addition of $6 \%$ lime decreased significantly the plasticity. Other researchers carried out the stabilization of clay soil with fly ash in a $5 \%, 10 \%$ and $20 \%(\mathrm{w} / \mathrm{w})$ content of dry soil, as well as with a mixture of cement and fly-ash at $2 \%$ and $4 \%$ on dry soil. They found that fly-ash-free $\mathrm{CaO}$ and cement react with the clay constituents ( $\mathrm{SiO} 2$ and other silicates) producing formation of tobermorite and hydrated aluminosilicates which contribute to increasing mechanical resistance [14]. The addition of cement gives a higher resistance to early age compared to fly-ash.

In this work, a laboratory scale study is presented with aim to contribute to knowledge related with anticorrosion properties of soil modification. In this paper, the assessment of anticorrosive properties of soils to which was added lime, fly-ash and cement in different percentages are shown. The goal is to find a system which provides a greater protection against corrosion for structures made of carbon steel.

\section{EXPERIMENTAL PROCEDURE}

\section{Sample preparation}

In this research, A-36 carbon steel coupons of $10 \mathrm{x}$ $20 \mathrm{x} 0.3 \mathrm{~cm}$ in size were sand blasted to $\mathrm{Sa} 3$ grade (white metal). 


\section{Soil modification with the addition of cementitious agents}

Soil modification is a process by which natural soils are subject to a certain manipulation or treatment to take their best qualities obtaining a firm and stable soil capable of supporting the transit effects and severe weather conditions. Soil modification changes soil characteristics producing a long-term or permanent mechanical resistance and stability.

In this research the soils has been modified to establish whether anticorrosive effects can be achieved on buried metallic structures. The used soil was previously classified as high plasticity silt, with a pH value of 6.5 which corresponds to a typology of soils reported in the literature as aggressive for buried metallic structures [15]. In order to increase the aggressiveness of the soil, a hydrochloric acid solution was added to it obtaining a soil with a $\mathrm{pH}$ of 3.5 and a chloride concentration of $0.3 \%$. This soil was named as reference soil. Due to the quantity of chloride added and taking into account the values of chloride concentration in soil (\% weight) reported in the literature, the reference soil is classified as soil of severe aggressivity [16].

Soil modification was made by an homogeneous mix of the reference soil with each cementitious agent such as lime (high calcium content, and a maximum of $5 \%$ of magnesium oxide or hydroxide), type $\mathrm{F}$ fly-ash (from combustion of lignite or anthracite, composed mainly by reactive silicate) and type I Portland cement (rich in $\mathrm{CaO}$ ) in a percentage of 5 and $10 \%$ in weight of dry soil. Eighty $\mathrm{Kg}$ of soil were prepared in total. Table 1 shows the composition of each cementitious agent. In order to avoid differences in oxygen concentration inside the modified soil, a mechanical homogenization was performed to ensure the same particle size between the soil and the cementitious agent.

\section{pH measurements}

After adding all cementitious material (Table 1), $\mathrm{pH}$ of the modified soils was monitored each 12 days during 60 days. Any chemical interaction between soil and cementitious materials could alter the $\mathrm{pH}$ value. $\mathrm{pH}$ measurements were performed according to ASTM G 51 [17], using a glass electrode (Boeko BA-17). $\mathrm{pH}$ values were directly taken from soil and they are shown as an average of 5 measurements.
Table 1. Chemical composition of cementitious materials.

\begin{tabular}{|l|c|c|c|}
\hline $\begin{array}{l}\text { Chemical } \\
\text { compound }\end{array}$ & $\begin{array}{l}\text { Fly-ash } \\
\text { (type F) }\end{array}$ & Lime & $\begin{array}{l}\text { Portland } \\
\text { Cement }\end{array}$ \\
\hline $\mathrm{SiO}_{2}$ & $\mathbf{5 4 . 9 0}$ & 0.53 & 22.60 \\
\hline $\mathrm{Al}_{2} \mathrm{O}_{3}$ & 25.80 & 0.21 & 4.30 \\
\hline $\mathrm{Fe}_{2} \mathrm{O}_{3}$ & 6.90 & 0.08 & 2.40 \\
\hline $\mathrm{CaO}$ & 8.70 & $\mathbf{9 4 . 6}$ & $\mathbf{6 4 . 4 0}$ \\
\hline $\mathrm{MgO}$ & 1.80 & 0.5 & 2.10 \\
\hline $\mathrm{SO}_{3}$ & 0.60 & 0.05 & 2.30 \\
\hline $\begin{array}{l}\mathrm{Na}_{2} \mathrm{O} \& \\
\mathrm{~K}_{2} \mathrm{O}\end{array}$ & 0.60 & 0.3 & 0.60 \\
\hline
\end{tabular}

\section{Electrochemical Impedance Spectroscopy}

Corrosion of buried carbon steel coupons in modified soils, with and without cementitious material addition, was evaluated in time by electrochemical impedance spectroscopy (EIS) in a classic there-electrode cell with a working area of $400 \mathrm{~cm}^{2}$. Figure 1 shows the assembly of the electrochemical cell used.

The measurements of EIS were carried out using a three electrode cell in which the working electrode was steel coupons vertically buried in soil to a depth of $5 \mathrm{~cm}$ to decrease differential aeration. The total exposed surface was $400 \mathrm{~cm}^{2}$. An electrode of copper/ copper sulphate was used as a reference electrode and a stainless steel 304 grid as counter electrode. In each soil with and without addition of cementitious agent, duplicate coupons were exposed with the objective of calculating the average impedance measurements and to obtain better reliability of the data. All data were reported as an average of the impedance measurements made at two coupons exposed in similar conditions.

Impedance measurements were carried out in potentiostatic mode at the open circuit potential, using a potentiostat-galvanostat Gamry Reference 600 . The impedance spectra were registered in a frequency range of $100 \mathrm{kHz}$ to $5 \mathrm{mHz}, 10$ points/ decade, $10 \mathrm{mV}$ of amplitude. Figure 1 shows the assembly of the electrochemical cell used. All measurements were carried out at room temperature $\left(22^{\circ} \mathrm{C}\right.$, approx.). The total exposure time was 60 days. Rust on carbon steel coupons were characterized by Raman Spectroscopy using a micro-Raman spectrometer Horiba Jovin Yvon, with a radiation of 
$632,8 \mathrm{~nm}$, D2 filter and acquisition times between 30 and 50 seconds in a wave number range of 100 and $1750 \mathrm{~cm}^{-1}$.

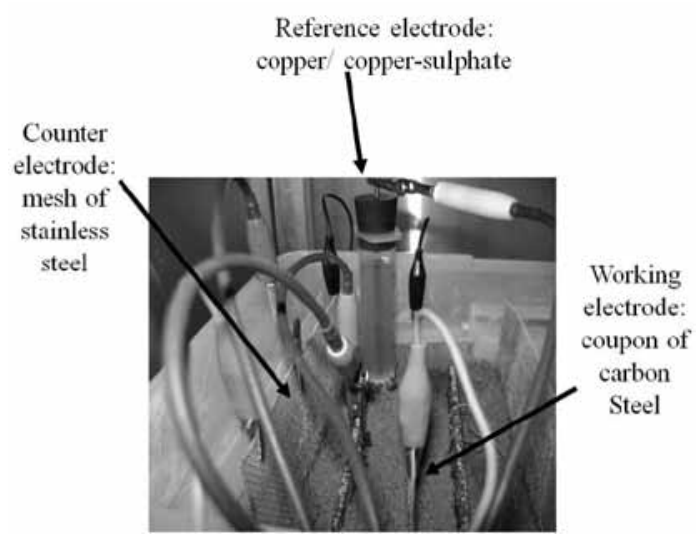

Figure 1. Electrochemical cell for soils evaluation.

\section{RESULTS AND DISCUSSION}

pH modification by addition of cementitious agents Soils do not usually have a $\mathrm{pH}$ less than 5 , on the contrary they have a higher $\mathrm{pH}$ between 5 and 8 . However, $\mathrm{pH}$ is not the only parameter that affects soil aggressiveness. In the present study, $\mathrm{pH}$ was decreased to a value less than 5 to obtain unfavorable conditions of the soil. Differences of aeration, influence of sulphate-reducing bacteria and, organic material decomposition were not considered.

Figure 2 shows the evolution of soil $\mathrm{pH}$ values in time with and without addition of cementitious materials. Soil $\mathrm{pH}$ without cementitious material was 3.5 and remained constant throughout the measurement time. However soil pH increased to a value close to 6.0 with addition of fly-ash in 5\% and $10 \%$ to the soil. This value tended to increase in time to 7.5. Higher additions of fly-ash did not change soil $\mathrm{pH}$. The texture of modified soil with fly-ash did not suffer significant changes; it only exhibited change of color. The pozzolans are known as siliceous or siliceous-aluminous materials without cementitious properties, but in a mixture with soil, pozzolans reacting with calcium hydroxide $\left(\mathrm{Ca}(\mathrm{OH})_{2}\right)$ to produce compounds with cementitious properties. One of the benefits of the fly-ash is that it provides high resistance to sulphates. Because of that, it is recommended to use when the concrete is exposed to soils containing sulphate ions and when concrete is at contact with underground water [18].
By using fly-ash as cement replacement in concrete increasing of strength and durability is obtained [19]. For all the above, the assessment of fly-ash as soil modifier is appealing.

There are two ways to modify soils with Portland cement. The first one is called flexible-type modification in which the percentage of cement varies between 1 and 5\%. This modification makes soil decreases its plasticity and reaches a very low increase of mechanical resistance. The other one is known as a rigid modification in which the percentage of cement is higher and varies between 6 and 15\%; this modification is more common because it provides significant increase of mechanical strength [20].

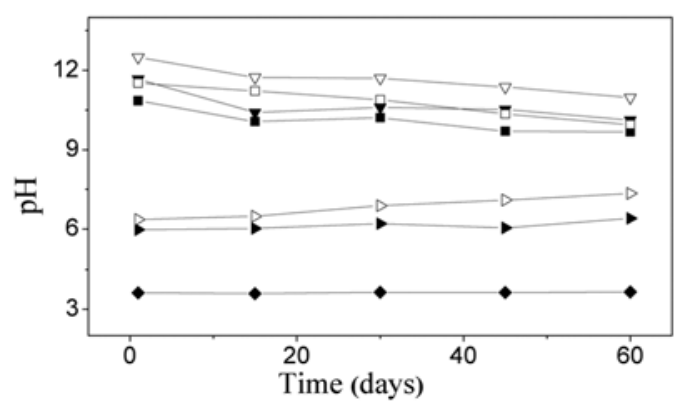

$\checkmark$ lime $5 \% \rightarrow$ - lime $10 \% \rightarrow$ fly-ash $5 \% \rightarrow$ fly-ash 1

- cement $5 \%-\square$-cement $10 \% \multimap$ Reference

Figure 2. $\mathrm{pH}$ evolution in time of modified soils with different cementitious materials.

As it can be seen in Figure 2, the addition of cement between 5 and $10 \%$ to the soil led to a pH increase to 11 and 11.6 respectively, however both of them reached a $\mathrm{pH}$ value of 10 after 60 days. The initial increase of $\mathrm{pH}$ is typical of cementitious systems because the cement has a higher content in $\mathrm{Ca}(\mathrm{OH})_{2}$; so there will be a greater amount of hydroxyl anions [20]. As a consequence, the texture of soil suffers appreciable modifications. This feature makes that the mechanical strength of the soil increases, as has been reported in literature. The mixture of soil, cement and water produces two reactions. The first one is caused by cement itself; a mortar is formed by hydration and a skeleton with silt sand [21]. The second one occurs in three phases: phase 1 , the hydration of cement promotes cement layer formations in the surface of agglomerated silt. Lime, which is released during the hydration, reacts immediately with soil and it is quickly consumed. In phase 2 , the hydration progress and the degradation 
of agglomerates of soil are activated. In phase 3, cement interacts with agglomerates of soil and the hydration persists slowly. According to the reactions above mentioned, different type of soil structures (a sandy structure linked to cement, stabilized soil and unstabilized soil) can be obtained.

Initially, the addition of $5 \%$ of lime increases soil $\mathrm{pH}$ to a value of 11.8. After 15 days of exposure, $\mathrm{pH}$ value decreased to a value close to 10 and remained constant. With the addition of $10 \%$ of lime to soil the $\mathrm{pH}$ increases to 12.5 , later decreases to 10.5 . As a consequence of this addition, the texture of soil underwent big changes in mechanical strength. Increasing of soil $\mathrm{pH}$ breaks the clay particles in the soil, releasing silica and alumina, which can react with the calcium of silt to produce hydrated calcium silicates and hydrated calcium aluminates. These compounds are cementitious products similar to those formed in Portland cement. They form the matrix of hard compounds that help to increase the mechanical strength of the soil. The modification in the soil structure from a granular sandy material to a moderately hard waterproof layer produces changes in the load capacity of the soil. The process begins within hours and may continue for years in a properly designed system. The matrix formed is permanent, producing a structural layer which is strong and flexible.

When lime is used to modify soils, chemical reactions occur immediately, the soil humidity hydrates lime releasing heat and producing a soil drying. The heat generated evaporates the residual humidity; after that, lime reacts with clay particles [13]. After initial mixture, $\mathrm{Ca}^{2+}$ ions of the hydrated lime emigrate to the clay particles surface along with water and other ions. The soil is friable, making it easier to work with (workable). At this stage, the index of soil plasticity decreases dramatically as well as its tendency to swell and contract. This process, called flocculation and agglomeration, generally occurs within a few hours $[3,20]$. Due to soil is usually modified with a quantity of lime between 1 and $8 \%$, physical-chemical changes can happen in that. Loamy soils modified by the addition of lime improve its plasticity, shrinkage index and are bonded to form calcium silicate [20]. It is believed that into the physical-chemical mechanism of the phenomenon of soil modification, $\mathrm{Ca}(\mathrm{OH})_{2}$ dissociates into the controlled environment. The hydroxyl ions released increases the $\mathrm{pH}$ value which favors the substitution of $\mathrm{Ca}^{2+}$ ions for other cations existent in soil. A more negative soil will attract more $\mathrm{Ca}^{2+}$ ions to reach saturation point which is the retention point mentioned above [21]. In the current work the intention is to provide protection against corrosion to structures buried in loamy soils and, as observed in Figure 2, percentages higher than $5 \%$ do not produce additional increase in the soil $\mathrm{pH}$ values, and maybe no additional anti-corrosion properties will be expected.

\section{Corrosion evaluation by electrochemical impedance spectroscopy (EIS)}

The EIS diagrams for carbon steel coupons after 1 and 60 days of exposure in soils with and without addition of cementitious material in a percentage of $5 \%$ in weight of soil are shown in Figure 3. These diagrams are composed by at least three capacitive arcs, which are characteristic of the time constants of three different electrode processes. According to their evolution in time, it can be said that the first arc characterized the metal charge transfer process in parallel with the electrical double layer; the second capacitive arc, is associated to the rust formed; and the third arc is associated to the diffusion process of species through the rust. The time constants of the previous processes are overlap due to the characteristic heterogeneity of the soil and to the quick rust formation, having similar time constants. Therefore, these impedance arcs are not well defined and the impedance diagram appears flattened, making the analysis and interpretation of the results difficult, even by using equivalent circuits. Other researchers have obtained the same results in a mixture of sand and clay [22]. Nevertheless, it is possible by using extrapolations in the limits of high and low frequencies to obtain values of soil resistance (Rs) and polarization resistance of the steel (Rp), respectively [23]. Both resistances were used to compare the electrochemical behavior of carbon steel exposed to different soils with the addition of cementitious material. Soils with addition of $10 \%$ of cementitious material exhibited similar impedance diagrams to those observed in soils with different additions.

In general, small changes were obtained in the impedance diagrams with the exposure time, which indicates that mechanism of corrosive process did not suffer considerable alterations through the time 
for a same soil. Great changes were observed at low frequencies in the impedance diagrams, showing a decrease compared to the initial value. Many studies indicated that generally steel corrosion in soil, on its initial stages, is determined by the resistance to charge transfer coupled to the diffusion of electro active species $[22,24]$. After the incubation time, the corrosive process is mainly determined by diffusion.

Arpaia, Pernice and Costantini [25] evaluated the corrosion of steel in clay soils and they found that in short exposures the corrosive process is controlled by hydrogen diffusion joined by the cationic exchange reaction of the clay particles. However for long exposures, the process is only controlled by diffusion. For these reasons the Nyquist impedance plot of a steel electrode in soil is not a simple semicircle, but may assume various shapes which have to be analyzed in terms of kinetic parameters. This confirms the validity of our results. Scully and Bundy [26] reports an elliptical behavior of Nyquist plots of steel exposed to Ohio soil for an exposure from 2 to 404 hours. Kasahara and Kijayama [27] reported elliptical plots from the beginning to a few days of exposure for steel in clay and sand. Quite different trends were obtained for longer exposures.

Figure 4 shows the variation of the polarization resistance (Rp) for carbon steel (taken at the limit of low frequencies of the EIS diagrams) and the soil resistance (Rs) for carbon steel (taken at the limit of high frequencies of the EIS diagrams) in soils with and without addition of cementitious material. In soil without addition of cementitious material the Rs remains constant at a value close to $2.3 \mathrm{kOhm} . \mathrm{cm}^{2}$. While Rp values present a tendency to decrease from $7.2 \mathrm{kOhm} . \mathrm{cm}^{2}$ (in the first days of the test) to $4.6 \mathrm{kOhm} . \mathrm{cm}^{2}$ (after 60 days of exposure). It can be inferred that the deterioration of the steel coupons by corrosion in this medium could be significative. It is known that a soil with low resistivity is generally corrosive [28, 29]. According to the value of the soil resistance (Rs) found for the reference soil, and considering that the distance between electrodes (counter electrode and reference) was $2.0 \mathrm{~cm}$, a value of resistivity of $1150 \mathrm{ohm} . \mathrm{cm}$ could be calculated. This value of resistivity is characteristic of corrosive soils.

Analyzing the effect of the additions of lime and cement in 5 and $10 \%$ in weight, it is observed
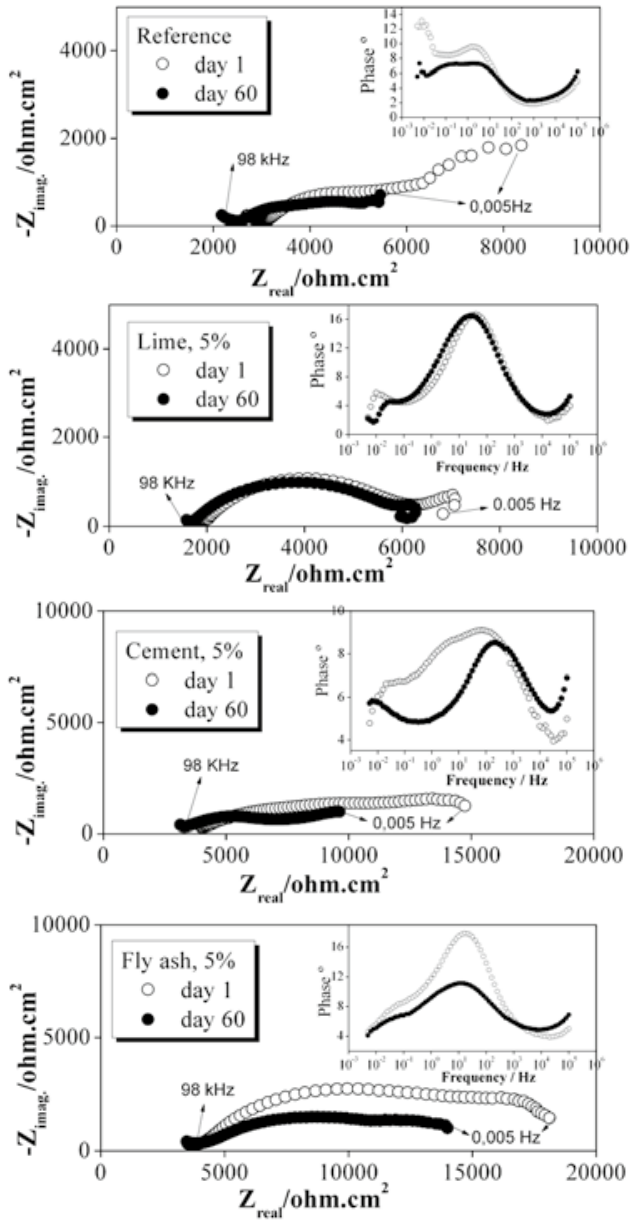

Figure 3. Impedance diagrams of carbon steel samples buried in reference soil and soils modified with $5 \%$ of lime, fly-ash and cement, after 1 and 60 days of exposure. Bode plots inserted.

that with the addition of $5 \%$ of lime or cement Rs presents values close to $2.0 \mathrm{kOhm} . \mathrm{cm}^{2}$, which are slightly lower than those observed in reference soil, while with $5 \%$ of fly-ash keeps the same. On the other hand, the addition of $10 \%$ of any of the three cementitious materials does not generate increase in electrical resistance of the soil respect to the reference, obtaining values close to $2.5 \mathrm{kOhm} . \mathrm{cm}^{2}$. It can be said that the addition of cementitious material greater to $5 \%$ does not guarantee an increasing in electrical resistance of soil. This indicates that although soil modification with cementitious material generates changes in the contexture of soil and improvements in its mechanical properties, there are not necessarily changes in its electrical properties. 
The lower variation in electrical properties could be explained by the fact that the soil was acidified with $\mathrm{Cl}^{-}$ions with the purpose of increasing the aggresivity of the soil and decreasing the response time in the corrosion test. The chloride ions are very mobile and are good electrical charge transporters, which makes the electrical conductivity does not suffer changes with the presence of chloride ions in the medium, despite the soil modification with cementitious material.

The polarization resistance $(\mathrm{Rp})$ values of the buried steel in modified soils with cementitious materials are higher than those observed in reference soil, except for the addition of 5\% of lime (Figure 4). The addition of cement and fly-ash in 5\% produced values of polarization resistance of $8.5 \mathrm{kOhm}$. $\mathrm{cm}^{2}$ and $9.0 \mathrm{kOhm} . \mathrm{cm}^{2}$, respectively, at the end of 60 days. While with addition of $10 \%$ of the same materials, the polarization resistances were 7.0 $\mathrm{kOhm} . \mathrm{cm}^{2}$ and $6.0 \mathrm{kOhm} . \mathrm{cm}^{2}$.

Taking into account that the increase of Rp cannot be associated to the increase of electrical resistivity of the soil, it is predictable that this increase in electrical resistance is due to more protective rust formation on the surface of the steel [30]. As it will be showed by Raman spectroscopy, there were not important changes in the composition of the rust generated in different modified soils, that means there may be a differentiating effect in the compaction of the rust generated by the cementitious materials. The generation of iron oxides finely divided on the steel substrate leads to the formation of a compact rust with well barrier properties inhibiting or limiting the passage of aggressive agents. In the current work this can be noticed by the polarization resistance increasing through the time in the steel coupons buried in soils modified with cementitious materials.

According to electrochemical impedance, it can be concluded that: the anticorrosive protection offered by cementitious materials does not completely depend on $\mathrm{pH}$ since the polarization resistance of the steel in soils with $\mathrm{pH}$ higher or equal than 10 is very similar to the obtained with soils with $\mathrm{pH}$ lower than 10. In addition, the electrical resistance of soil shows little variations by the addition of the cementitious material. However, the addition of cementitious material retards the corrosive
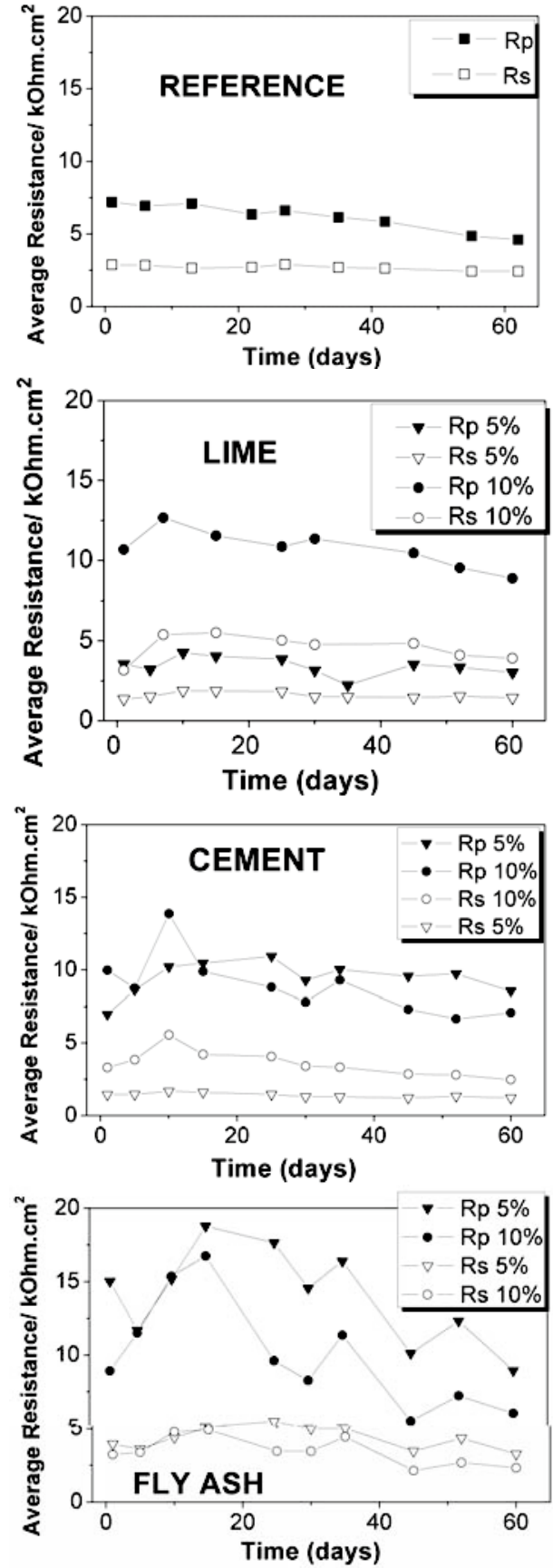

Figure 4. $\mathrm{Rp}$ and Rs variation over the time for reference soil and soil with addition of $5 \%$ and $10 \%$ of cementitious materials.

process of the material which can be reflected in the increasing and stabilization of the polarization resistance over the time; similar to that occurred with the long term increase of mechanical resistance due 
to the progressive crystallization of the new mineral species, which are produced by reactions between cementitious materials and soil [31].

As it was mentioned above, this study was developed under the hypothesis that the increase in $\mathrm{pH}$ of the soil by the addition of cementitious materials can promote conditions in which protective rust can be generated. From this point of view, the materials which can validate this hypothesis are the cement and lime since both confer to the soil a high alkalinity while fly-ash only achieves increasing in $\mathrm{pH}$ values close to 7. According to Pourbaix [32], at $\mathrm{pH}=7$ iron must to be at an active corrosion state; however, the values of polarization resistance of carbon steel buried in soil modified with fly-ash are comparable to those obtained with soil modified with cement and lime. This could occur because fly-ash is constituted by little and fine particles with spherical form which can be located in empty spaces of the soil, reducing the porosity of soil and acting as a barrier to diffusion, so limiting the access of aggressive agents $[19,33]$.

\section{Characterization of corrosion products}

Because of the addition of the cementitious agents in the soil and the consequent increase of the $\mathrm{pH}$ in the soil, the rust formed in the steel can be modified substantially. According to the potential-pH diagram for iron [32], the oxides and hydroxides of iron, which tend to form in high values of $\mathrm{pH}$, have protective character, enabling the passivation of the iron or steel in the same way like happen in the reinforcing steel embedded in concrete [34, 35].

In order to verify that hypothesis, a characterization of the corrosion products formed on carbon steel samples exposed to reference and modified soils with different additions of cementitious materials, was carried out by Raman spectroscopy. In Figure 5 Raman spectra of rust formed in the steel exposed to different modificated soils are shown. In that rust, two regions were observed: one light red region and a dark brown. The light red region of the rust is mainly constituted by goethite $(247,380,470$, $\left.550,690 \mathrm{~cm}^{-1}\right)$ and lepidocrocite $(305,390,530$, $650 \mathrm{~cm}^{-1}$ ), in according to the characteristics bands of these compounds consulted in the literature [36-40]. These compounds are present in the rust formed, independently if the soil was or was not modified with cementitious materials. Moreover, it could be observed that in the dark region of the reference soil and soil modified with 5\% of lime, in addition to goethite and lepidocrocite, there is an important presence of magnetite $\left(667 \mathrm{~cm}^{-1}\right)[36,38]$. This situation does not occur in the dark brown rust formed in soils modified with cement and fly-ash. The presence of chloride ion could preclude the passivation of the steel by the formation of soluble compounds, even though if it is in an alkaline medium $(\mathrm{pH}>9.0)$ [36]. It is well know that in weathering steels the production of amorphous goethite makes possible the formation of protective rusts; while the presence of magnetite into the rust makes it more active and less compact, enabling the subsequent oxidation of the substrate [40]. In this work was found that the presence of cement and fly-ash in the soil contaminated with chlorides prevents or limits the formation of magnetite into the rust, enabling the formation of protective rust while in the reference soil and in the soils modified with lime, magnetite forms easily and the rust does not have protective characteristics. The protective characteristic of the rust generated on steel samples buried in modified soils with cement and fly-ash is coherent with the results obtained by the electrochemical impedance technique, where it was found a higher polarization resistance in those soils. The presence of maghemite $\left(385,505,520,665,720 \mathrm{~cm}^{-1}\right)[36,39,40]$ could be occurred by the dehydration of the lepidocrocite caused by thermal effects induced by the laser in the Raman technique. Because the stability of the surface with respect to the laser depends on their morphology, and therefore cannot ignore the damage the laser may cause to a sample, no matter its intensity [39-44].

\section{Visual inspection of the probes}

Once the exposure time was ended the steel samples were retired from the soils and cleaned. The samples deterioration was analyzed by visual inspection. In Figure 6 it is observed that samples that present a lower deterioration were those samples buried in soil modified with fly-ash. It does not observe an important difference between samples buried in soil modified with 5\% and $10 \%$ of fly-ash. The samples buried in soil with addition of lime, in both percentages, are those which present a higher deterioration; a uniform corrosion in the surface was observed. The coupons buried in soil with addition of cement showed a localized corrosion with intermediate deterioration between fly-ash and lime. This deterioration is low when cement is added 

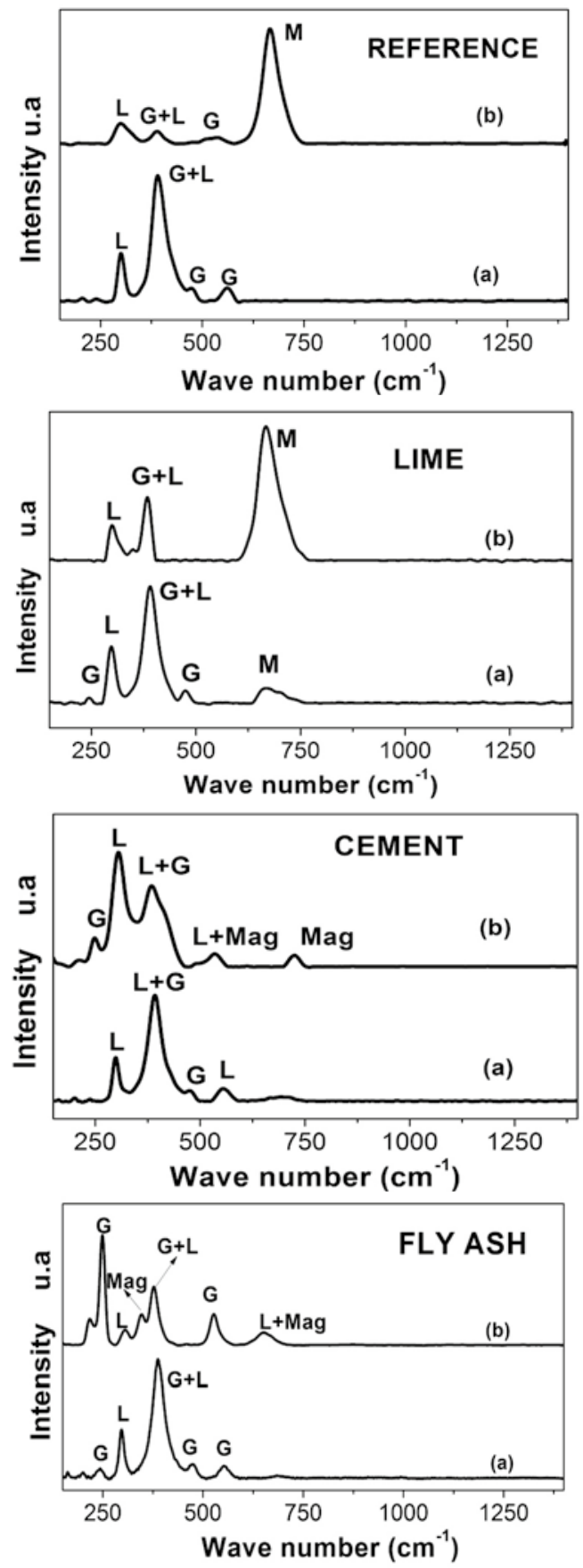

Figure 5. Raman spectra of corrosion products formed on carbon steel exposed to soil with and without addition of $5 \%$ of cementitious materials. The spectra were taken in regions of the rust with different color: (a) Light red. (b) Dark brown. at $5 \%$. The sample buried in soil without addition of cementitious materials (reference) overcomes, in all cases, the surface deterioration exhibited by samples buried in soil modified with cementitious material. The visual inspection of the carbon steel coupons agree with the results showed by the electrochemical impedance technique where the higher values of polarization resistance were obtained in soils modified with fly-ash and cement at $5 \%$.

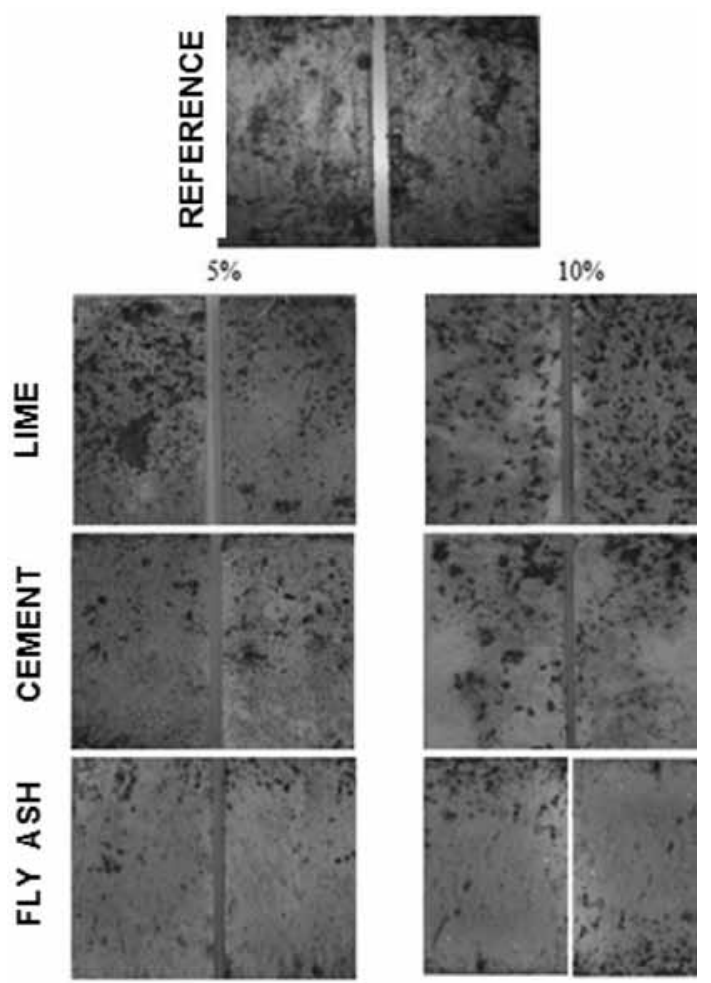

Figure 6. Samples of carbon steel extracted from the soils modified with and without addition of cementitious materials after 60 days of exposure.

\section{CONCLUSIONS}

According to the obtained results in this study the most effective anticorrosive procedure for acid soils is to add $5 \%$ of fly-ash or cement to the soil.

The addition of cement and lime in proportion of $5 \%$ and $10 \%$ achieve a high alkalinity of the soil which allows obtaining $\mathrm{pH}$ values close to 10 ; however, this is not an enough condition to provide protective properties to the soil when it is acid and contaminated with chloride ions. 
Additions higher than 5\% of cementitious materials to the soil, do not reach an additional effect in anticorrosive protection. This only implicates physical changes in mechanical properties of the soil.

\section{ACKNOWLEDGEMENTS}

The authors thank Universidad de Antioquia, Universidad de Medellin, COLCIENCIAS and Interconexión Eléctrica S.A. (ISA) for the financial support given to this project (1115-06-17879).

\section{REFERENCES}

[1] G. Trabanelli, F. Zucchi and M. Arpaia. "Methods of determination of soil corrosiveness with respect to metallic structures". Chim pura Applicata III Vol. 4 , pp. 43-59. 1972.

[2] C.A. Ferreira, J.A. Ponciano, D.S. Vaitsman and D.V. Pérez. "Evaluation of the corrosivity of the soil through its chemical composition". Science of The Total Environment. Vol. 388, pp. 250-255. 2007.

[3] National Lime Association. "Manual de estabilización de suelo tratado con cal". Publicación de la National Lime Association. Boletín 326. 2004. Fecha de consulta: 2 de mayo de 2010. URL: http://www.lime.org/ documents/publications/free_downloads/ construct-manual-spanish2004.pdf

[4] R.N. Yong and V.R. Ouhadi. "Experimental study on instability of bases on natural and lime/cement-stabilized clayey soils". Applied Clay Science. Vol. 35, pp. 238-249. 2007.

[5] Q.-S. Yang and C.-J. Li. "Evolution of properties in hydration of cements- A numerical study". Mechanics Research Communications. Vol. 33, pp. 717-727. 2006.

[6] G.S. Xeidakis. "Stabilization of swelling clays by $\mathrm{Mg}(\mathrm{OH}) 2$ - Changes in clay properties after addition of $\mathrm{Mg}$-hydroxide". Engineering Geology. Vol. 44, pp. 107-120. 1996.

[7] M. Vicente y C. Pinto. "Valoración de la adición de cal en mezclas de suelo-asfalto". Revista de Obras Públicas. Vol. 3, No 5, pp. 312-323. Mayo 1962.

[8] M. Estrada, E. Alonso, L.E. Chávez, H.L. Chávez, W. Martínez, J.C. Rubio, F. Velasco y M. Ávalos. "Hidratación del Cemento Pórtland, fase Etringita; Monosulfatos y
Trisulfatos". $1^{\circ}$ Foro Académico de la DES de Ingenierías y Arquitectura de la Universidad Michoacana de San Nicolás de Hidalgo. Morelia, Michoacán, México. 2005.

[9] N. Otsuki, W. Yodsudjai and T. Nishida. "Feasibility study on soil improvement using electrochemical technique". Construction and Building Materials. Vol. 21, pp. 1046-1051. 2007.

[10] D. de la Fuente, J. Simancas and M. Morcillo. "Effect of variable amounts of rust at the steel/paint interface on the behaviour of anticorrosive paint systems". Progress in Organic Coatings. Vol. 46, pp. 241-249. 2003.

[11] C.I. Elsner, E. Cavalcanti, O. Ferraz and A.R. Di Sarli. "Evaluation of the surface treatment effect on the anticorrosive performance of paint systems on steel". Progress in Organic Coatings. Vol. 48, pp. 50-60. 2003.

[12] C. Pérez, A. Collazo, M. Izquierdo, P. Merino and X.R. Nóvoa. "Characterisation of the barrier properties of different paint systems: Part II. Non-ideal diffusion and water uptake kinetics". Progress in Organic Coatings. Vol. 37, pp. 169-177. 1999.

[13] A.W.H. Amer, A. Al-Rawas and H. Al-Sarmi. "Effect of lime, cement and Sarooj (artificial pozzolan) on the swelling potential of an expansive soil from Oman". Building and Environment. Vol. 40, pp. 681-687. 2005.

[14] S. Kolias, V. Kasselouri-Rigopoulou and A. Karahalios. "Stabilization of clayey soils with high calcium fly ash and cement". Cement and Concrete Composites. Vol. 27, pp. 301-313. 2005.

[15] E.E. Oguzie, I.B. Agochukwu and A.I. Onuchukwu. "Monitoring the corrosion susceptibility of mild steel in varied soil textures by corrosion product count technique". Materials Chemistry and Physics. Vol. 84, pp. 1-6. 2004.

[16] M. Maslehuddin, M.M. Al-Zahrani, M. Ibrahim, M.H. Al-Mehthel and S.H. Al-Idi. "Effect of chloride concentration in soil on reinforcement corrosion". Construction and Building Materials. Vol. 21, pp. 1825-1832. 2007.

[17] ASTM. "Standard Test Method for Measuring $\mathrm{pH}$ of Soil for Use in Corrosion Testing". 
Annual Book of ASTM Standards. American Society for Testing and Materials. 1995.

[18] S.K. Malhotra and N.G. Dave. "Investigations into the effect of addition of fly ash and burnt clay puzzolana on certain engineering properties of cement composites". Cement and Concrete Composites. Vol. 21, pp. 285291. 1999.

[19] J. Bijen. "Benefits of slag and fly ash". Construction and Building Materials. Vol. 10, pp. 309-314. 1996.

[20] C.F.D. García A. and J.A. Polanco. "Evolution of penetration resistance in fresh concrete". Cement and Concrete Research. Vol. 38, pp. 649-659. 2008.

[21] M.L.Payán. "Estabilización de sahcab con cemento Pórtland Tipo I para la construcción de pisos en viviendas rurales". Ingeniería Revista Académica. Vol. 6 No 2, pp. 33-45. 2002.

[22] P. Pernice, M. Arpaia and A. Costantini. "Steel Corrosion Rate in Soils by a.c. and d.c Electrochemical Methods". Materials Chemistry and Physics. Vol. 26, pp. 323-330. 1990.

[23] D.A. Koleva, J.H.W. de Wit, K. van Breugel, L.P. Veleva, E. van Westing, O. Copuroglu and A.L.A. Fraaij. "Correlation of microstructure, electrical properties and electrochemical phenomena in reinforced mortar. Breakdown to multi-phase interface structures. Part II: Pore network, electrical properties and electrochemical response". Materials Characterization. Vol. 59, pp. 801815. 2008.

[24] X.H. Nie, X.G. Li, C.W. Du and Y.F. Cheng. "Temperature dependence of the electrochemical corrosion characteristics of carbon steel in a salty soil". J. Appl. Electrochem. Vol. 39, pp. 277-282. 2009.

[25] M. Arpaia, P. Pernice and A. Costantini. "Kinetic Mechanism of Steel Corrosion in Clay Soils by Impedance Measurements". Materials Chemistry and Physics. Vol. 24, pp. 373-382. 1990.

[26] J.R. Scully and R.J. Bundy. "Electrochemical Measurements of Steel Pipe Corrosion Rates in Soil". Materials Performance. Vol. 24, Issue 4, pp. 18-25. 1985.

[27] F. Kajiyama and K. Kasahara. "Application of AC impedance measurements to underground monitoring”. Corrosion. Vol. 39, pp. 296-302. 1983.

[28] E. López, A. Osella and L. Martino. "Controlled experiments to study corrosion effects due to external varying fields in embedded pipelines". Corrosion Science. Vol. 48, Issue 2, pp. 389-403. 2006.

[29] D. Neff, P. Dillmann, M. Descostes and G. Beranger. "Corrosion of iron archaeological artifacts in soil: Estimation of the average corrosion rates involving analytical techniques and thermodynamic calculations". Corrosion Science. Vol. 48, Issue 10, pp. 2947-2970. 2006.

[30] J.J. Rayuela. "Corrosión y Protección de Estructuras Metálicas". Consejo Superior de Investigaciones Científicas. Madrid, España. 1991.

[31] J.B. Croft. "The Structures of Soils Stabilized With Cementitious Agents". Engineering Geology. Vol. 2, pp. 63-80. 1967.

[32] M. Pourbaix. "Atlas of electrochemical equilibria in aqueous solutions". NACE -CEBELCOR. National Association of Corrosion Engineers, p. 332. 1974.

[33] G. Li and X. Zhao. "Properties of concrete incorporating fly ash and ground granulated blast-furnace slag". Cement and Concrete Composites. Vol. 25, pp. 293-299. 2003.

[34] A. Poursaee and C.M. Hansson. "Reinforcing steel passivation in mortar and pore solution". Cement and Concrete Research. Vol. 37, pp. 1127-1133. 2007.

[35] P. Ghods, O.B. Isgor, G. McRae and T. Miller. "The effect of concrete pore solution composition on the quality of passive oxide films on black steel reinforcement". Cement and Concrete Composites. Vol. 31, pp. 2-11. 2009.

[36] S.J. Oh, D.C. Cook and E. Townsend. "Characterization of iron oxides commonly formed as corrosion products on steel". Hyperfine interactions. Vol. 112, pp. 59-66. 1998.

[37] R. Balasubramaniam, A.V.R. Kumar and P. Dillmann. "Characterization of rust on ancient indian iron". Current Science. Vol. 58, pp. 1546-1555. 2003.

[38] H.G.M. Edwards, E.M. Newton and J. Russ. "Raman spectroscopic analysis of pigments and substrata in prehistoric rock art". Journal of Molecular Structure. Vol. 550, pp. 245256. 2000. 
[39] M. Bouchard and D.C. Smith. "Catalogue of 45 reference Raman spectra of minerals concerning research in art history or archaeology, especially on corroded metals and coloured glass". Spectrochimica Acta Part A: Molecular and Biomolecular Spectroscopy. Vol. 59, pp. 2247-2266. 2003.

[40] M. Hanesch. "Raman spectroscopy of iron oxides and (oxy) hydroxides at low laser power and possible applications in environmental magnetic studies". Geophysical Journal International. Vol. 177, pp. 941-948. 2009.

[41] T. Okada, Y. Ishii, T. Mizoguchi, I. Tamura, Y. Kobayash, Y. Takagi, S. Suzuki, H. Kihira, M. Ituo, A. Usami, K. Tanabe and M.K. Mössbauer. "Studies on Particle Volume Distribution of a-FeOOH in Rust Formed on Weathering Steel". J. Appl. Phys. Vol. 39, pp. 3382-3391. 2000.

[42] T. Ohtsuka, K. Kubo and N. Sato. "Raman Spectroscopy of Thin Corrosion Films on Iron at 100 to $150 \mathrm{deg}$ C in Air". Corrosion. Vol. 42, pp. 476-481. 1986.

[43] D.L.A. de Faria, S. Venancio and M.T. de Oliveira. "Raman Microspectroscopy of Some Iron Oxides and Oxyhydroxides". Raman Spectroscopy. Vol. 28, pp. 873-878. 1997.

[44] T.S. Gendler, V.P. Shcherbakov, M.J. Dekkers, A.K. Gapeev, S.K. Gribov and E. McClelland. "The lepidocrocite-maghemite-haematite reaction chain-I. Acquisition of chemical remanent magnetization by maghemite, its magnetic properties and thermal stability". Geophysical Journal International. Vol. 160, pp. 815-832. 2005. 